\title{
Periphytic algae dynamics in lentic ecosystems in the Brazilian semiarid
}

\author{
R. S. Cordeiro ${ }^{a *}$, J. E. L. Barbosa ${ }^{a}$, G. Q. Lima Filho ${ }^{a}$ and L. G. Barbosa ${ }^{b}$ \\ ${ }^{a}$ Laboratório de Ecologia Aquática, Departamento de Biologia, Centro de Ciências Biológicas - CCBS, \\ Universidade Estadual da Paraíba - UEPB, Campus I, Av. das Baraúnas, 151, Bloco Três Marias, \\ CEP 58428-500, Campina Grande, PB, Brazil

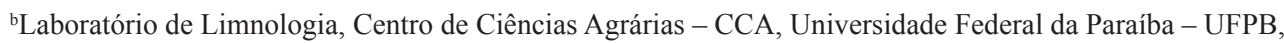 \\ Campus II, Rodovia PB-079, CEP 58397-000, Areia, PB, Brazil \\ *e-mail: raqquel.cordeiro@gmail.com
}

Received: October 13, 2015 - Accepted: March 27, 2016 - Distributed: August 31, 2017

(With 5 figures)

\begin{abstract}
The hydrological periods drive the structure and organization of aquatic communities in semiarid regions. We hypothesize that a decrease of the precipitation during the dry period will favor the development of the periphytic algal community, leading to higher richness and density in this period. To test this hypothesis, we investigated the changes in the periphytic algal community structure in three shallow and eutrophic ecosystems of the Brazilian semiarid. The sampling was performed between 2007 and 2010 at two-mensal intervals. The sampling of periphytic algal was performed in aquatic macrophytes and rocks. The abiotic variables were analyzed simultaneously. Dominance in diatoms, cyanobacteria and chlorophytes, respectively, was observed in two periods. In the dry period, waters were alkaline and had high concentrations of nitrate and total phosphorus associated with the highest densities of Bacillariophyceae. In the rainy period the water was warmer, oxygenated and high concentrations of ammonia and soluble reactive phosphorus with diatoms remained dominant but with reduced density, while cyanobacteria and chlorophytes increased. Overall, periphytic algal community composition no responded to changes in the hydrological periods. However, the hydrological periods altered the dynamics of periphytic algal community, supported by the alternation of the most representative classes (diatoms and cyanobacteria) between the hydrologic periods. Our data suggest that the morphometric and chemical and physical characteristics of lentic aquatic ecosystems studied were more important in the dynamics of periphytic algal community than the hydrological periods and types of substrates.
\end{abstract}

Keywords: seasonality, reservoirs, lentic aquatic ecosystems, periphyton.

\section{Estrutura da comunidade de algas perifíticas do semiárido brasileiro}

\section{Resumo}

Os períodos hidrológicos impulsionam a estrutura e organização das comunidades aquáticas em regiões semiáridas. Nós hipotetizamos que uma diminuição da precipitação durante o período seco irá favorecer o desenvolvimento da comunidade de algas perifíticas, levando a uma maior riqueza e densidade nesse período. Para testar esta hipótese, nós investigamos as mudanças na estrutura da comunidade de algas perifíticas em três ecossistemas rasos e eutróficos do semiárido brasileiro. As amostragens foram realizadas entre 2007 e 2010 em intervalos de bimensais. A amostragem das algas perifíticas foi realizada em macrófitas aquáticas e rochas. As variáveis abióticas foram analisadas simultaneamente. A dominância de diatomáceas, cianobactérias e clorófitas, respectivamente, foi observada em todos os períodos. No período seco, as águas foram alcalinas com altas concentrações de nitrato e fósforo total associado às maiores densidades de Bacillariophyceae. Durante o período chuvoso as águas apresentaram-se mais quentes, oxigenadas e com altas concentrações de amônia e fósforo reativo solúvel. As diatomáceas permaneceram dominantes, mas com densidade reduzida, enquanto as cianobactérias e clorofíceas aumentaram. No geral, a composição da comunidade de algas perifíticas não respondeu as mudanças nos períodos hidrológicos. No entanto, os períodos hidrológicos alteraram a dinâmica da comunidade de algas perifíticas, apoiados pela alternância das classes mais representativas (diatomáceas e cianobactérias) entre os períodos hidrológicos. Nossos dados sugerem que as características morfométricas, químicas e físicas dos ecossistemas aquáticos lênticos estudados foram mais importantes na dinâmica da comunidade de algas perifíticas do que os períodos hidrológicos e tipos de substratos.

Palavras-chave: sazonalidade, reservatórios, ecossistemas aquáticos lênticos, perifíton. 


\section{Introduction}

The periphytic algal community is primarily autotrophic and plays an important role as primary producers in the littoral zone of aquatic ecosystems (Vadeboncoeur and Steinman, 2002; Nozaki et al., 2003). Periphyton structure changes affect the growth, development, survival and reproduction of many aquatic organisms (Campeau et al., 1994). In addition, algal periphytic acts as excellent bioindicator of water quality and its trophic state (Lobo, 2013). This aspect was emphasized by several researchers (Vercellino and Bicudo, 2006; Bere and Tundisi, 2010; Lobo et al., 2010).

The structure and spatial-temporal dynamics of periphytic algal communities in aquatic ecosystems are directly associated to climatic, hydrodynamic and abiotic conditions, as well as specific biological characteristics (Stevenson, 1996; Larned, 2010) and type and quality of the substrate (Rodrigues et al., 2005). In different scales, the type of substrate, hydrological regime (dry and rainy periods) and amplitude of inter-annual fluctuations in the volume of water have crucial roles in the composition of periphytic algal communities in semiarid aquatic ecosystems.

Interannual variability in rainfall associated to high evaporation rates (Crispim and Freitas, 2005) and low levels of rainfall are the main factors promoting changes in Brazilian semiarid aquatic ecosystems (Barbosa et al., 2012). The hydrological regime in the Brazilian semiarid region drives the structure of biotic communities and plays a fundamental role in the organization of communities in relation to space (Barbosa et al., 2012). In this region, the hydrological regime acts as an indirect agent of disturbance with significant effects on the structure and function of the periphytic algal community (Peterson, 1996). However, the disturbances occur for periphytic algae when a process or external condition your physiology that result in mortality of community biomass in a shorter time than the accumulation of biomass (Huston, 1994).

In the semiarid region, especially in Brazil, there is little information about the effects of hydrological cycles and hydrological disturbance events on periphytic algal community. Thus, this community is not well studied and thus little understood. Therefore, assess this community is important to understand its structure and dynamics, particularly in semi-arid region where drought and rain are a key factor in the hydrological dynamics and ecological processes (Almeida et al., 2012; Eskinazi-Sant'Anna et al., 2013).

In this context, the main purpose of this study was to analyze the structure and dynamics of the periphytic community under the effects of the hydrological periods (dry and rainy period) in three lentic aquatic ecosystems in semiarid region. According to the assumption that the hydrological regimes promote variation in the structure of the periphytic algae community, we tested the hypothesis that hydrological regimes affect the structure and dynamics this community. Thus, we expected that the periphytic algal community presenting the highest richness, and density in the dry period due to the decreased of precipitation during this period favoring the development of the community. Besides, we also analyzed the structure and dynamics of the periphytic community among the lentic aquatic ecosystems studied. Additionally, we investigate the composition of species present in epiphytic and epilithic substrates in the three lentic aquatic ecosystems. We expected that the periphytic algal community composition was different between substrates analyzed, and among the lentic aquatic ecosystems studied.

\section{Material and Methods}

\subsection{Study area}

The Taperoá River basin (6॰51'31" and 8²6’21'S; $34^{\circ} 48^{\prime} 35^{\prime \prime} \mathrm{W}$ and $37^{\circ} 2^{\prime} 15^{\prime} \mathrm{W}$ ) (Figure 1) occupies an area of $20,071.83 \mathrm{~km}^{2}$ in the semiarid region of Brazil (AESA, 2015). The region has a hot semiarid climate (BSwh') and a bioclimatic sub-desert hot zone with a tropical trend (Köppen, 1948). Mean annual temperature varies between $25^{\circ} \mathrm{C}$ and $30^{\circ} \mathrm{C}$, and rainfall varies between $200 \mathrm{~mm}$ and $800 \mathrm{~mm} /$ year distributed mainly from January to June (Pedro et al., 2006).

Three aquatic ecosystems were studied: two reservoirs and a pond (Figure 1).

The reservoirs were chosen because are mostly used as water supply to urban areas, while the Panati pond to be a temporary environment with little studies about periphytic algal community. Taperoá II reservoir (7'11'44'S; 36 $\left.52^{\prime} 03^{\prime \prime} \mathrm{W}\right)$ has a maximum depth of $5.7 \mathrm{~m}$ (AESA, 2015), and its littoral zone houses aquatic macrophytes with prominent Eichhornia sp. Kunth and Egeria sp. Planchon. Soledade reservoir (7²'14'S; $36^{\circ} 22^{\prime} 38^{\prime}$ 'W) has a maximum depth of $15 \mathrm{~m}$ and, differently from Taperoá II, it does not house aquatic macrophytes. Panati pond ( $7^{\circ} 11^{\prime} 14^{\prime} \mathrm{S}$; $\left.36^{\circ} 49^{\prime} 52^{\prime \prime} \mathrm{W}\right)$ is a shallow and small ecosystem, with $100 \mathrm{~m}$ long, $25 \mathrm{~m}$ wide and $1.5 \mathrm{~m}$ of maximum depth in rainy periods (Crispim and Freitas, 2005). This pond had aquatic macrophytes with prominent Eichhornia sp. e Nymphaea sp. Linnaeus.

\subsection{Sampling and variables analyzed}

Sampling was performed two-month intervals from October/2007 to December/2010 in the sub-surface in the littoral zone of the ecosystems. We performed 16 sampling in triplicates in each environment studied.

Rainfall data ( $\mathrm{mm}$ ) were obtained from the Executive Agency for Water Management in the State of Paraíba (AESA, 2015). Dry and rainy periods were determined using monthly average rainfall between August/2007 and December/2010: rainy periods were considered from January to July and dry periods from August to December. These periods were determined from the average of rainfall recorded for 30 years. Monthly values of rainfall provided by meteorological stations located in the municipalities where ecosystems are inserted are shown in Figure 2.

Measurements of water temperature $\left({ }^{\circ} \mathrm{C}\right), \mathrm{pH}$ and electrical conductivity were obtained with portable digital 

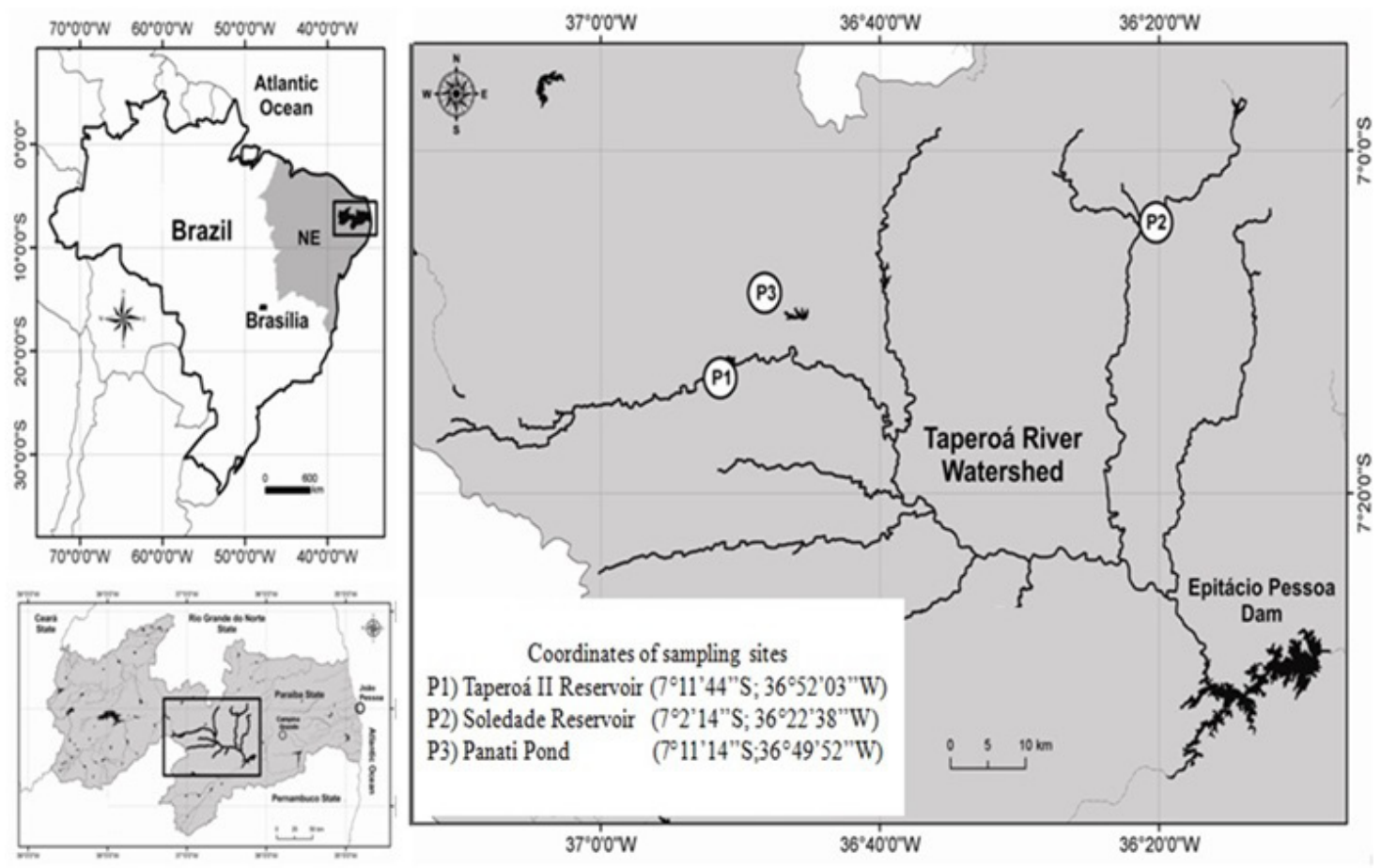

Figure 1. Taperoá River basin in the semiarid region of Paraíba (Brazil) and sampling reservoirs.

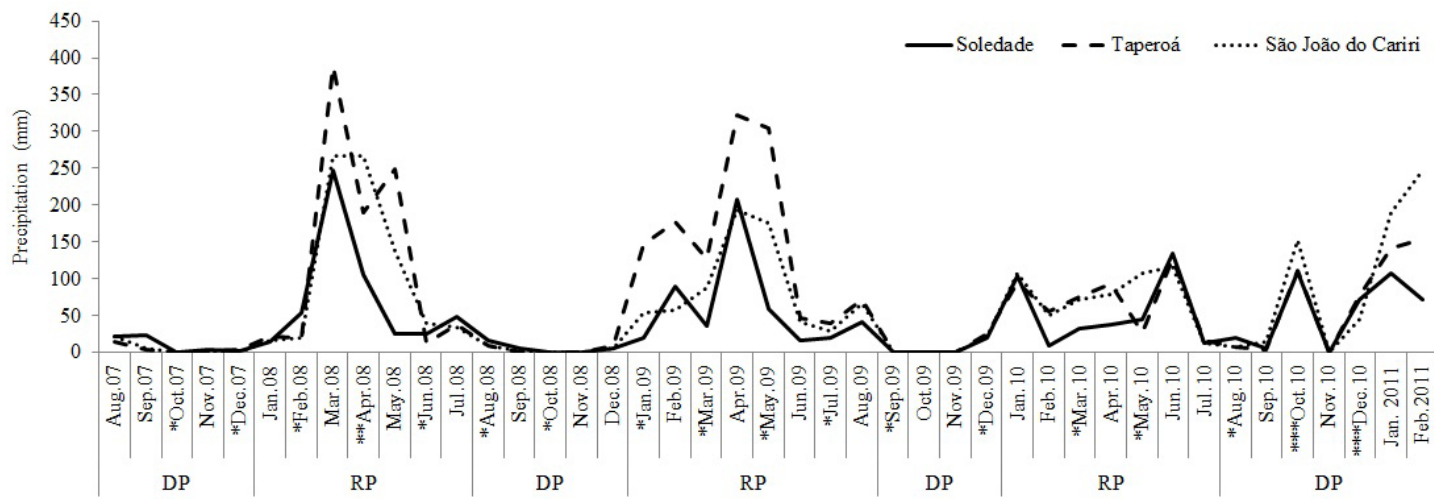

Figure 2. Monthly values of precipitation from August/2007 to December/2010, according to data provided by meteorological stations located in the towns of Taperoá, Soledade and São João do Cariri. (*) Sampling; (**) There was no sample; $(* * *)$ Unusual rain.

potentiometers (COLE-PARMER, portable digital). Water transparency was measured with a Secchi disk (Cole, 1994). Water samples were collected in PVC bottles previously cleaned with distilled water, and stored in containers with ice for transportation to the laboratory where they were frozen and had their nitrite $\left(\mathrm{N}-\mathrm{NO}_{2}^{-}\right)$, nitrate $\left(\mathrm{N}_{-} \mathrm{NO}_{3}^{-}\right)$, ammonium $\left(\mathrm{N}_{-} \mathrm{NH}_{4}^{+}\right)$, soluble reactive phosphorus $\left(\mathrm{P}-\mathrm{PO}_{4}{ }^{3-}\right)$, total phosphorous (TP) and silica concentrations determined according to APHA (1998). Dissolved oxygen concentration was determined through Winkler method (Golterman et al., 1978), and alkalinity was determined according to Mackereth et al. (1978). The Carlson's Trophic State Index (TSI) (Carlson, 1997) adapted by Toledo Junior (1990) for tropical region was used to classify the ecosystems into oligotrophic (TSI $<45$ ), mesotrophic $(\mathrm{TSI}=45-55)$ or eutrophic $(\mathrm{TSI}>55)$. The parameters used to the TSI were: dissolved phosphorus, total phosphorous, chlorophyll $a$, and transparency of water.

\subsection{Periphytic algal community}

For the analyses of species composition and density of periphytic algal community, we collected three samples from each ecosystem in each of the months evaluated. In each ecosystem were performed the scraping in rocky substrates and aquatic macrophyte petioles, as follows Taperoá II reservoir: seven samples in rocky substrates and nine samples in aquatic macrophyte petioles of Eichhornia sp.; Soledade reservoir: 16 samples in rocky substrates; and 
Panati pond: nine samples in rocky substrates and seven samples in aquatic macrophyte petioles of Eichhornia sp. The substrates were not standardized because in all sampled months they were not available for collection due to hydrologic periods.

Periphytic algal material was removed from the substratum (area $=1 \mathrm{~cm}^{2}$ ), and removed from the substrate with brushes and jets of distilled water, and fixed and preserved with $4 \%$ formalin for the qualitative analyses and in Lugol's solution for the quantitative analyses. For taxonomic identification of diatoms, oxidization and preparation permanent slides were provided followed Hasle and Fryxell (1970) and Naphrax ${ }^{\circledR}(I R=1.7)$ was used as the inclusion medium.

The classification system adopted for level class was the Van-den-Hoek et al. (1995) and Bicudo and Menezes (2006) for genus. The periphytic community was identified using specialized literature for each group of algae: Prescott et al. (1982), Anagnostidis and Komárek (1988), Hegewald and Silva (1988), Komárek and Anagnostidis (1989), Sant'Anna (1984), Tell and Conforti (1986), Round et al. (1990) and Bicudo and Menezes (2006). For specific level was used specialist literature.

Algal quantifications were performed by the method of Utermöhl (1958) and organisms were quantified using an inverted microscope (Zeiss, AxioVert). Sedimentation time of samples and counting was conducted through of the transects according to Lund et al. (1958) until the most frequent species reached 100 individuals (percentage error less than $20 \%$ and assurance coefficient of 95\%). Results were expressed in number of individuals per unit area (ind. $\mathrm{cm}^{-2}$ ).

\subsection{Data analysis}

Data was submitted to a basic descriptive statistical analysis. The structure and dynamics of the community was assessed from its main attributes such as taxa richness, density and dominant species, considered the total taxa with densities greater than 50\% (Lobo and Leighton 1986).

Differences in composition of species of periphytic algae between the substrates, and between ecosystems, and between rainy and dry periods were identified by means of a PERMANOVA, utilizing 9,999 permutations, with Bray-Curtis as a measure of dissimilarity and $p<0.05$ as the criterion of significance. This statistical analysis was performed in Primer 6 version 6.1.13 and PERMANOVA+ version 1.0.3.

In order to detect significant differences in periphytic algae density between the substrates, and among ecosystems, and between rainy and dry periods, one-way Analysis of Variance (ANOVA) was performed. Assumptions of normality and homoscedasticity required by this analysis were previously tested. For this analysis, periphyton density were $\log$-transformed $[\log (\mathrm{x}+1)]$. This statistical analysis was performed in Statistica 10.0 Statsoft (2011).

\section{Results}

\subsection{Physical and chemical characteristics}

Annual average rainfall was lower than $300 \mathrm{~mm}$ (Table 1). Average water temperature was generally high (higher than $25^{\circ} \mathrm{C}$ ), with the highest value registered during the rainy period (higher than $28^{\circ} \mathrm{C}$ ).

The $\mathrm{pH}$ values ranged from 7.2 to 9.0 during all the period analysed, and highest values of $\mathrm{pH}$ were found in the dry period. High electrical conductivity was registered in all reservoirs with higher values during the dry period $\left(6,630 \mu \mathrm{S} . \mathrm{cm}^{-1}, \mathrm{n}=16\right)$, with the exception of Panati pond that showed higher values in the rainy period (622.5 $\left.\mu \mathrm{S} . \mathrm{cm}^{-1}, \mathrm{n}=16\right)$. All reservoirs showed moderate concentrations of dissolved oxygen (3.2-6.4 mg-1 $\mathrm{L}, \mathrm{n}=16$ ), with more oxygenated waters during the rainy period. Silica concentrations were low (mean values between 1.1 and $\left.20 \mu \mathrm{g} . \mathrm{L}^{-1}\right)$, with higher values during the rainy period (mean values between 2-20 $\mu \mathrm{g}^{-\mathrm{L}^{-1}}$ ) (Table 1).

High $\mathrm{N}_{-} \mathrm{NH}_{4}^{+}$concentrations were recorded, with the highest nitrate concentrations were registered during the dry period (107-1,175.7 $\mu \mathrm{g}$. L L L $^{-1}$, exception of Taperoá II reservoir. The highest concentrations of ammonium and soluble reactive phosphorus (mean values between 14.9 and $1,006.4 \mu \mathrm{g} . \mathrm{L}^{-1}$ ) were observed in the rainy period. In this study, the trophic status index ranged from mesotrophic to eutrophic during all the period analysed, Taperoá II and Soledade reservoirs showed mesotrophic status during the rainy period and eutrophic status during the dry period while Panati pond was classified as eutrophic (Table 1).

\subsection{Periphytic algal community}

In total, we found 204 taxa of periphytic algae, distributed in the following classes: Bacillariophyceae (67), Chlorophyceae (55), Cyanobacteria (47), Euglenophyceae (12), Zygnemaphyceae (12), Chlamydophyceae (5), Oedogoniophyceae (5) and Dinophyceae (1). In relation to ecosystems analysed, Panati pond recorded higher number of taxa (158), followed to Taperoá II reservoir (106), and Soledade reservoir (99) (Figure 3A). In this study, the results of the PERMANOVA analysis showed difference between the algae composition in the three ecosystems studied $(p=0.0033)$. However, in relation to rainy and dry periods, was found no difference between the algae composition ( $p=0.4661$ ). In rainy period, the highest species richness was recorded in Panati pond (114 taxa), followed by Taperoá II reservoir (80), and Soledade reservoir (69). While, in the dry period, species richness found in Panati pond (108) was higher than the reservoirs ( 75 and 71 for Taperoá and Soledade, respectively) (Figure 3B).

In relation the substrate types, the results of PERMANOVA analysis showed no difference in the algae composition found in Taperoá II reservoir $(\mathrm{p}=0.6564)$ and Panati Pond $(p=0.1546)$. In Panati pond, we found 102 taxa in rocky substrates. These taxa were represented for Chlorophyceae (32), Cyanobacteria (27), Bacillariophyceae (26) and others (17). Whereas, in the vegetable substrates, were found 73 taxa in which were distributed in Bacillariophyceae (24), 


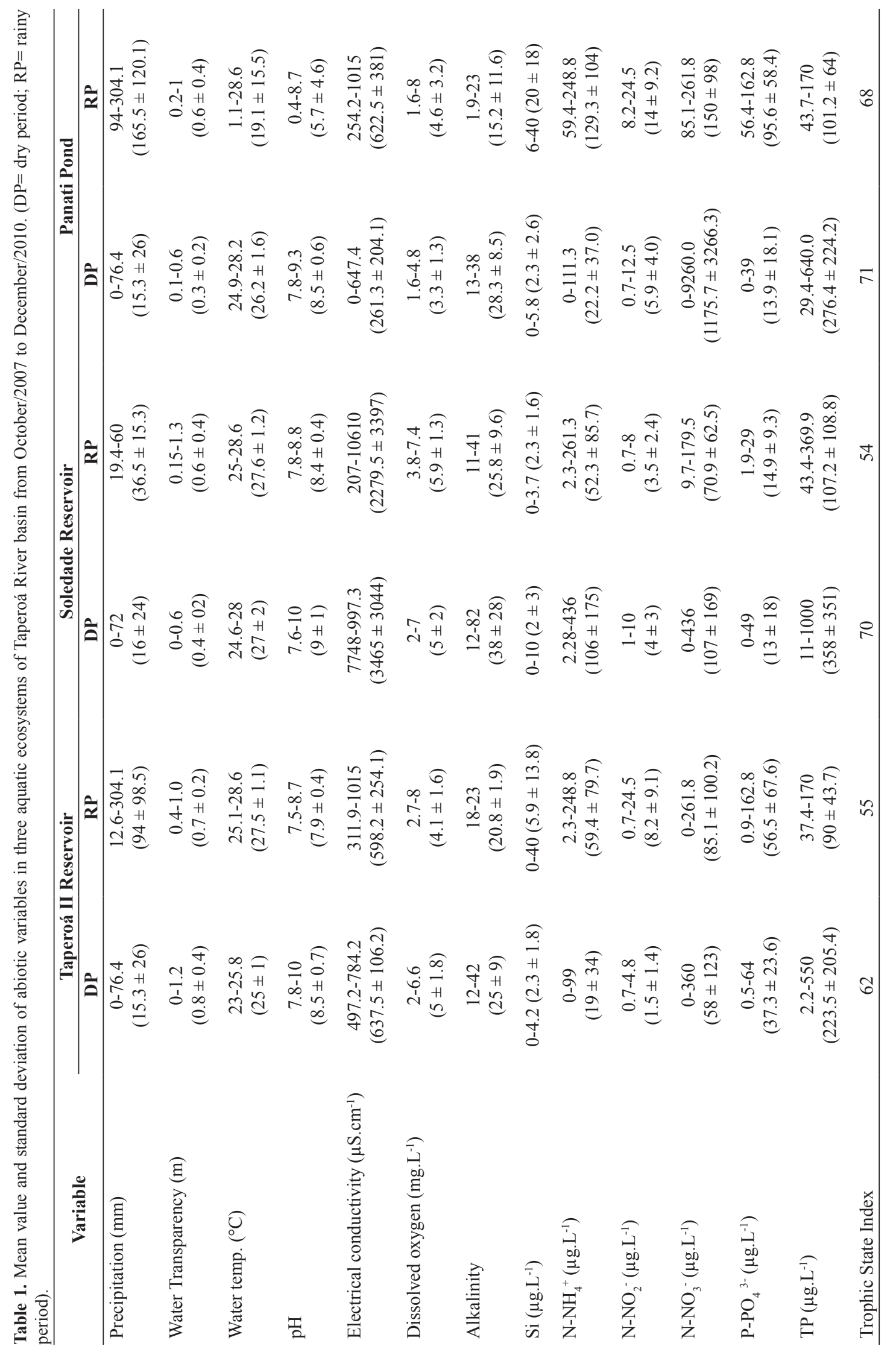


Chlorophyceae (17), Cyanobacteria (12), and others (20) (Figure 3C). On the other hand, the Taperoá II reservoir was recorded higher species richness in the vegetable substrate (64) than rocky substrate (54). In both types of substrates, the classes Bacillariophyceae (28 and 26, respectively) and Cyanobacteria (20 and 14, respectively) were the most representative (Figure 3C). Unlike these ecosystems, in the Soledade reservoir did not were realized collects in vegetable substrate due to absent these substrates in this ecosystem. Therefore, were recorded 99 taxa, distributed in Bacillariophyceae (36) and Cyanobacteria (25) and Chlorophyceae (23), and others (15) (Figure 3C).

In relation to total algal density, in the dry period, the highest values were recorded in Panati pond $\left(136,195\right.$ ind. $\left.\mathrm{cm}^{-2}\right)$,

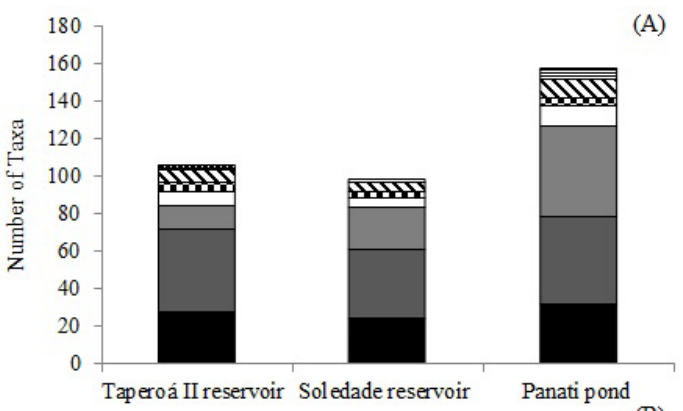

(B)
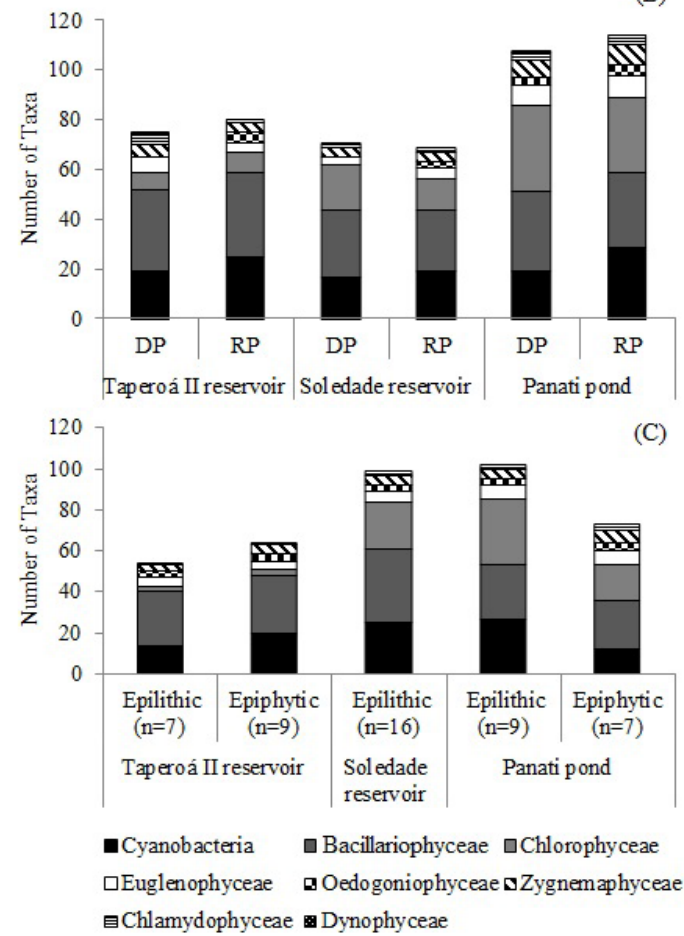

Figure 3. Richness of algae classes in the Bacillariophyceaeree aquatic ecosystems of Taperoá River basin from October/2007 to December/2010 (A); Richness of algae classes in the different hydrological periods in three aquatic ecosystems of Taperoá River basin from October/2007 to December/2010 (B); Richness of algae classes in two types of substrates collected in each aquatic ecosystems studied (C).
Taperoá II $\left(27,285\right.$ ind. $\left.\mathrm{cm}^{-2}\right)$ and Soledade reservoirs $\left(24,965\right.$ ind. $\left.\mathrm{cm}^{-2}\right)$ (Figure 4A). During the rainy period, the highest densities were recorded in Panati pond $\left(244,685\right.$ ind.cm ${ }^{-2}$ ) (Figure 4). As seen in Figure 4A, the total density of periphytic algae tended to increase in the rainy period. However, no significant differences in the total density between hydrological periods and the substrate types were recorded.

In general, Bacillariophyceae was predominant in all ecosystems and between the hydrological periods throughout the study (Figure 4B). Cyanobacteria were present in all environments, with higher density in the rainy season. In the Panati pond, unlike other environments, Chlorophyceae was the second most representative, with values exceeding Cyanobacteria density in both hydrological periods, especially during the rainy season. Oedogoniophyceae was recorded in both periods, and had its highest densities in the rainy period in Taperoá II and Soledade reservoirs (Figure 4B). Zygnemaphyceae, Chlamydophyceae and Dinophyceae were considered little representative throughout the study in each ecosystem studied (Figure 4B).

In relation to dominant taxa, during the dry period the dominant taxa in the periphytic community structure were: Fragilaria capucina Desmazière, Gloeotrichia sp., Oedogonium sp. and Rhopalodia sp. in Soledade reservoir; Aulacoseira granulata (Ehrenberg) Simonsen, Epithemia adnata (Kützing) Brébisson and Oedogonium sp. in
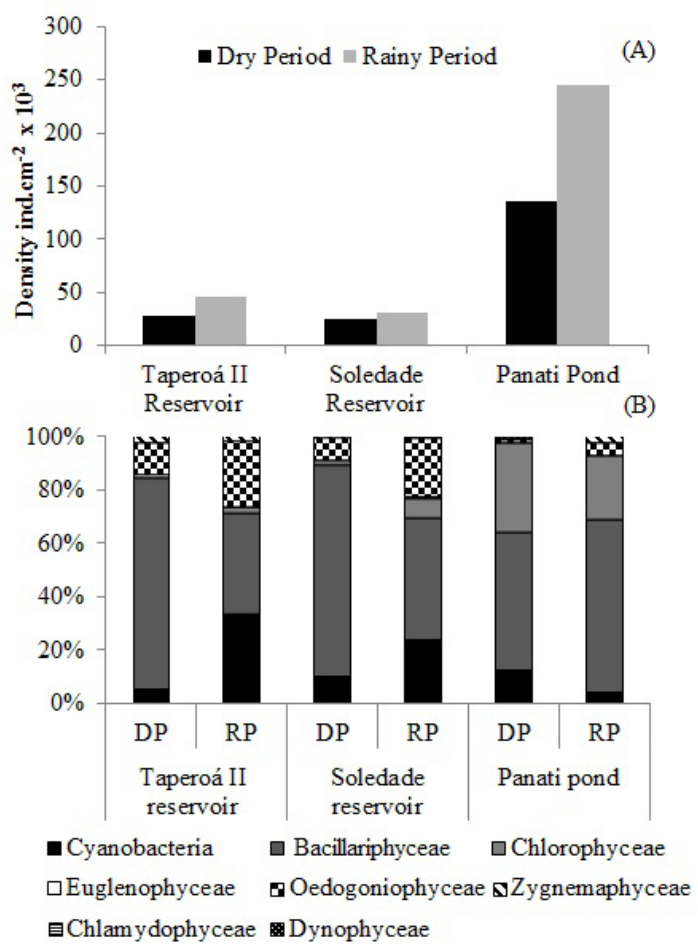

Figure 4. Total density of periphytic algae (ind. $\mathrm{cm}^{-2} \times 10^{3}$ ) in different hydrological periods (A); Relative abundance (\%) of algal classes in the different hydrological periods (B). $(\mathrm{DP}=$ dry period; $\mathrm{RP}=$ rainy period $)$. 


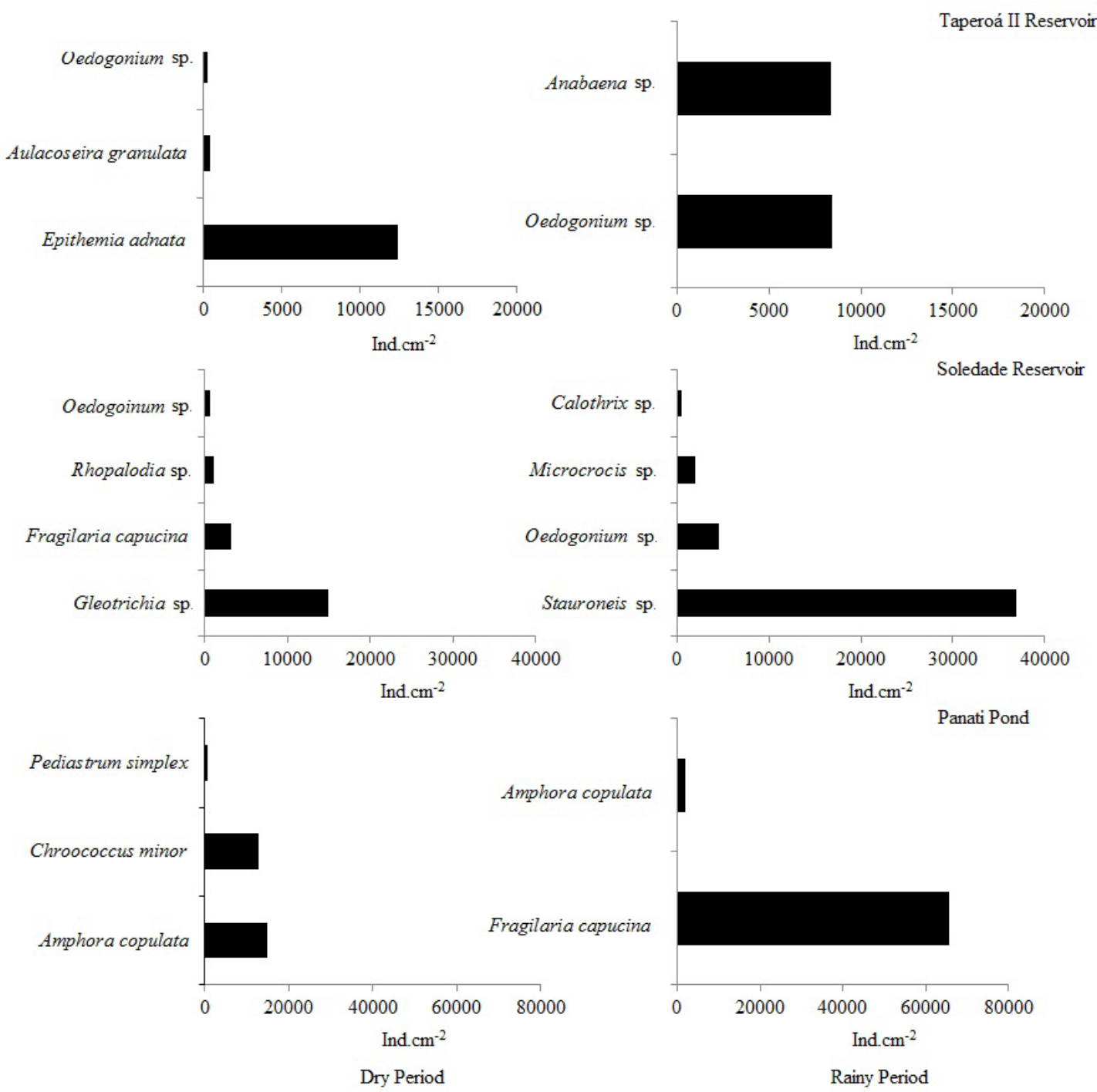

Figure 5. Contribution of dominant taxa of periphytic algal community in different hydrological periods $(\mathrm{DP}=\mathrm{dry}$ period; $\mathrm{RP}=$ rainy period).

Taperoá II reservoir and Amphora copulata (Kützing) Schoeman and Archibald, Chroococcus minor (Kützing) Nägeli and Pediastrum simplex Meyen in Panati pond (Figure 5), amounting to nine species. During the rainy period, the number of species reduced to seven, with four in Soledade reservoir (Calothrix sp., Microcrocis sp., Oedogonium sp. and Stauroneis sp.), two in Taperoá II reservoir (Anabaena sp. and Oedogonium sp.), and two in Panati pond (Amphora copulata and Fragilaria capucina) (Figure 5).

\section{Discussion}

Our hypothesis that the hydrological period may affect the structure and dynamics in the periphytic algae community was not supported by the data in this study. In addition, our hypothesis that different types of substrates had different algal composition also was not supported by the data in this study. Our results suggest that morphometric, chemical, and physical characteristics of lentic aquatic ecosystems studied had more importance in the structure and dynamics in the periphytic algae community than the substrates and hydrological periods in this study.

The seasonal dynamics in tropical aquatic ecosystems can be controlled by rainfall (e.g. Felisberto and Rodrigues, 2005), especially in the semiarid region, where two seasons are well characterized (dry and rainy). These act strongly in the level of water, in the nutrient concentration and, consequently, in the hydrochemical state of the ecosystem (Miretzky et al., 2002). In this study, in the rainy period was recorded warmer waters, oxygenates and with high concentrations of ammonia, orthophosphate and silica which can be favored the coexistence of species and consequently increasing the periphytic algal density due 
to highest diversity of resources available in this period. In contrast, the dry period was characterized by lower water transparency, high electrical conductivity, more alkaline waters and increase in the water trophic state. Results similar were found by Brasil et al. (2015) analyzing the physical and chemical variables of 40 man-made lakes in semiarid northeastern Brazil at the end of the rainy and dry periods.

In general, the ecosystems presented polymictic regimes with warm, alkaline, well-oxygenated and eutrophic waters during the entire study period. These characteristics, acting synergistically in all periods, together with high concentrations of phosphorus probably favored the species richness, especially in the Panati pond. The eutrophic condition and high electrical conductivity values in the studied ecosystems, probably favored the development of some species of diatoms tolerant to organic load. In the ecosystems with highest nutrients concentration were registered highest densities of diatoms. Among these Nitzschia palea, which was related with species that are highly tolerant of pollution in rivers (Lobo et al., 2010), Rhopalodia gibberula and Stauroneis sp. were related to low water temperatures in the dry period (approximately $20{ }^{\circ} \mathrm{C}$ ) in the studied ecosystems. According to Fonseca and Rodrigues (2005a) this temperature can be optimum for the development of these species in wetland ecosystem.

Diatoms are typical algal classes of the periphytic algae community. In this study, this class had greater representation in all ecosystems and between the periods studied. The individuals of this class are usually found well represented in a wide range of environments and periods (Cavati and Fernandes 2008; Taniwaki et al., 2013). According to Murakami et al. (2009), the diatom predominance is associated to its characteristic morphological and physiological of secrete mucilage which enable the attachment and adhesion to substrates. Besides, Dunck et al. (2013) reported that this characteristic provides a competitive advantage in less favorable environmental conditions imposed by volume reduction and current. Similarly, in this study, we observed an increasing in algal density this group in the reservoirs in the dry periods probably due to the increased environmental stability during this period.

In the study, greater representability of cyanobacteria in the rainy periods possibly was favored by limnological condition, such as highest temperature, and highest concentrations of nitrate, ammonium and soluble reactive phosphorus recorded in this period. According to Fonseca and Rodrigues (2005b) greater presence of cyanobacteria in the rainy season is related to different levels of features present in this period, as higher concentrations of nitrate and ammonium. In addition, Fernandes et al. (2009) reported that the toleration of cyanobacteria to high temperatures associated to its ability to utilize nitrogen forms make them extremely competitive compared to other groups of algae favoring its prevalence.

The greatest contribution of Chlorophyceae, both in species richness and density, was in Panati pond. Unlike other environments studied, this ecosystem had extensive macrophyte beds which are important substrates for the development of these algae. Macrophytes provide different habitat types for community development, e.g. metaphytic and periphytic, and also contributes to increased nutrient availability in the littoral zones (Taniguchi et al., 2005). In the Panati pond, was recorded dominance of Pediastrum simplex in the dry period. According to Padisák et al. (2009), this species is very common in waters rich in nutrients or eutrophic environments and are abundant in small lakes permanents or temporary.

Limnological conditions reported in Panati Pond such as nutrient availability, and high electric conductivity, and shallow lakes, and extensive bed of macrophyte promoting the development of species of the genus Euglenophyceae (Wetzel, 2001; Reynolds et al., 2002). According to Alves-da-Silva and Fortuna (2006), this algal class are well developed in shallow habitats covered by aquatic macrophytes that when we decompose favor the increase of organic matter in the environment.

The class Oedogoniophyceae, although poorly representative during the study, had greater participation in total density during rainy periods in all ecosystems studied. According to Cavati and Fernandes (2008), individuals of this class have a periphytic habit and are common during rainy periods. In addition, most species of this class are resistant to disturbance because they attach firmly to the substrate (Peterson, 1996). Therefore, probably these conditions have provided its predominance in the rainy period as recorded in this study.

In relation to hydrological periods, diatoms and cyanobacteria dominated the periphytic community. We observed highest densities of Bacillariophyceae in the dry period, whereas in the rainy period the cyanobacteria and chlorophytes increased. Result similar to found by Borduqui and Ferragut (2012) evaluating periphytic algal succession in a tropical hypereutrophic reservoir. The authors recorded higher dominance of diatoms in the dry period, while in the rainy period the cyanobacteria and Bacillariophyceae were the most representative groups.

According to Fernandes et al. (2009) almost all dominant Cyanobacteria can form filaments and are found typically associated with periphyton. In this study, two filamentous cyanobacteria dominated the algal periphytic community in the rainy period, while only one in the dry period. Results similar, has been documented by several authors in tropical in tropical reservoirs (e.g. Cavati and Fernandes, 2008; Fernandes et al., 2009; França et al., 2011).

The shallow lakes in the semiarid regions, such as the pond Panati, have high sensitivity to fluctuations of the water level being associated with drought periods at higher temperature, higher nutrient concentration (especially phosphorous), and resuspension nutrient factors associated one of the most catastrophic (Beklioglu et al., 2007). In this context, studies about these types of ecosystems are fundamental to the understanding of the aquatic community in semiarid regions which are unique and so variable habitats (Crispim and Freitas, 2005). 
In summary, periphytic algal community composition not responded to changes in hydrological periods (dry and rainy periods). However, the hydrological periods altered the dynamics of periphytic algal community that was dominated by diatoms, cyanobacteria and chlorophytes in the dry period, with greater dominance of species of the diatoms. In the rainy period, the pattern remained, but diatoms density was reduced and cyanobacteria and chlorophytes densities increased. In relation to type of substrates analysed, the algal composition was not different in each ecosystem studied. Our data suggest that the morphometric and chemical and physical characteristics of lentic aquatic ecosystems studied were more important in the dynamics of periphytic algal community than the hydrological periods. Once the natural pond (Panati pond) was recorded a distinct algal periphytic composition of the reservoirs. On the other hand, the physical and chemical conditions of these environments are directly associated the hydrologic periods. Thus, we observed that the limnological conditions favoured the structure and dynamics in the periphytic algae community, supported by the change of the most representative classes (diatoms and cyanobacteria) between the hydrologic periods.

\section{Acknowledgements}

The authors thank Universidade Estadual da Paraíba for logistical support, Conselho Nacional de Desenvolvimento Científico e Tecnológico (CNPq/PELD-CAATINGA) for financial support and Coordenação de Aperfeiçoamento de Pessoal de Nível Superior (CAPES) for a scholarship granted to the first author.

\section{References}

AGÊNCIA EXECUTIVA DE GESTÃO DAS ÁGUAS DO ESTADO DA PARAÍBA - AESA, 2015 [viewed 28 January 2015]. Recursos hídricos [online]. Paraíba: AESA. Available from: http://www.aesa.pb.gov.br/geoprocessamento/qualidade_agua/ acudes/index.html

ALMEIDA, V.L., MELÃO, M.G. and MOURA, A.N., 2012. Plankton diversity and limnological characterization in two shallow tropical urban reservoirs of Pernambuco State, Brazil. Anais da Academia Brasileira de Ciencias, vol. 84, no. 2, pp. 537-550. http://dx.doi.org/10.1590/S0001-37652012005000027. PMid:22534751.

ALVES-DA-SILVA, S.M. and FORTUNA, J.R., 2006. Euglenophyceae de ambientes lênticos na planície costeira do Rio Grande do Sul, Sul do Brasil: gêneros Euglena Ehr. E Lepocinclis Perty. Acta Botanica Brasílica, vol. 20, no. 2, pp. 411-422. http://dx.doi. org/10.1590/S0102-33062006000200016.

AMERICAN PUBLIC HEALTH ASSOCIATION - APHA, 1998. Standard Methods for the Examination of Water and Wastewater. 20th ed. Washington: APHA/AWWA/WPCF. 1193 p.

ANAGNOSTIDIS, K. and KOMÁREK, J., 1988. Modern approach to the classification system of cyanophytes 3- oscillatoriales. Algological Studies, vol. 80, no. 52, pp. 327-472.
BARBOSA, J.E.L., MEDEIROS, E.S.F., BRASIL, J., CORDEIRO, R.S., CRISPIM, M.C.B. and SILVA, G.H.G., 2012. Aquatic systems in semi-arid Brazil: limnology and management. Acta Limnologica Brasiliensia, vol. 24, no. 1, pp. 103-118. http:// dx.doi.org/10.1590/S2179-975X2012005000030.

BEKLIOGLU, M., ROMO, S., KAGALOU, I., QUINTANA, X. and BECARES, E., 2007. State of the art in the functioning of shallow Mediterranean lakes: workshop conclusions. Hydrobiologia, vol. 584, no. 1, pp. 317-326. http://dx.doi.org/10.1007/s10750007-0577-x.

BERE, T. and TUNDISI, J.G., 2010. Epipsammic diatoms in streams influenced by urban pollution, São Carlos, SP, Brasil. Brazilian Journal of Biology $=$ Revista Brasileira de Biologia, vol. 70, pp. 921-930. http://dx.doi.org/10.1590/S1519-69842010000500002.

BICUDO, C.E., and MENEZES, M., 2006. Gênero de algas de águas continentais do Brasil- Chave para identificação e descrição. 2nd ed. São Carlos: RiMa. 508 p.

BORDUQUI, M. and FERRAGUT, C., 2012. Controlling factors of successional periphytic algae in tropical hypereutrophic reservoir. Hydrobiologia, vol. 683, pp. 109-122. http://dx.doi.org/10.1007/ s10750-011-0943-6.

BRASIL, J., ATTAYDE, J.L., VASCONCELOS, F.R., DANTAS, D.D. and HUSZAR, V.L., 2015. Drought-induced water-level reduction favors cyanobacteria blooms in tropical shallow lakes. Hydrobiologia, vol. 770, no. 1, pp. 1-20. http://dx.doi.org/10.1007/ s10750-015-2578-5.

CAMPEAU, S., MURKIN, H.R. and TITMAN, R.D., 1994. Relative importance of algae and emergent plant litter to freshwater marsh invertebrates. Canadian Journal of Fisheries and Aquatic Sciences, vol. 51, no. 3, pp. 681-692. http://dx.doi.org/10.1139/f94-068.

CARLSON, R.E., 1977. A trophic state index for lakes. Limnology and Oceanography, vol. 22, no. 2, pp. 361-380. http://dx.doi. org/10.4319/lo.1977.22.2.0361

CAVATI, B. and FERNANDES, V.O., 2008. Algas perifíticas em dois ambientes do baixo rio Doce (lagoa Juparanã e rio Pequeno Linhares, Estado do Espírito Santo): variação espacial e temporal. Acta Scientiarum Biological Sciences, vol. 30, no. 4, pp. 439-448. http://dx.doi.org/10.4025/actascibiolsci.v30i4.535.

COLE, G.A., 1994. Textbook of limnology. 4th ed. Illinois: Waveland Press. 337 p.

CRISPIM, M.C. and FREITAS, G.T., 2005. Seasonal effects on zooplanktonic community in a temporary lagoon of Northeast Brazil. Acta Limnologica Brasiliensia, vol. 17, no. 4, pp. 385-393.

DUNCK, B., NOGUEIRA, I.S. and FELISBERTO, S.A., 2013. Distribution of periphytic algae in wetlands (Palm swamps, Cerrado), Brazil. Brazilian Journal of Biology $=$ Revista Brasileira de Biologia, vol. 73, no. 2, pp. 331-346. http://dx.doi.org/10.1590/ S1519-69842013000200013. PMid:23917560.

ESKINAZI-SANT'ANNA, E.M., MENEZES, R., COSTA, I.S., ARAÚJO, M., PANOSSO, R. and ATTAYDE, J.L., 2013. Zooplankton assemblages in eutrophic reservoirs of the Brazilian semi-arid. Brazilian Journal of Biology $=$ Revista Brasileira de Biologia, vol. 73, no. 1, pp. 37-52. http://dx.doi.org/10.1590/ S1519-69842013000100006. PMid:23644787.

FELISBERTO, S.A. and RODRIGUES, L., 2005. Comunidade de algas perifíticas em reservatórios de diferentes latitudes. In: L. RODRIGUES, S.M.T. THOMAZ, A.A. AGOSTINHO and L.C. GOMES, eds. Biocenoses em reservatórios: padrões espaciais e temporais. São Carlos: RIMA, pp. 7-114. 
FERNANDES, V.O., CAVATI, B., SOUZA, B.D., MACHADO, R.G. and COSTA, A.G., 2009. Lagoa Mãe-Bá (Guarapari-Anchieta, ES): um ecossistema com potencial de florações de cianobactérias? Oecologia Brasiliensis, vol. 13, no. 2, pp. 366-381. http://dx.doi. org10.4257/oeco.2009.1302.10.

FONSECA, I.A. and RODRIGUES, L., 2005a. Comunidade de algas perifíticas em distintos ambientes da planície de inundação do Alto Rio Paraná. Acta Scientiarum. Biological Sciences, vol. 27, no. 1, p. 21-28. http://dx.doi.org10.4025/actascibiolsci.v27i1.1354.

FONSECA, I.A. and RODRIGUES, L., 2005b. Cianobactérias perifíticas em dois ambientes lênticos da planície de inundação do Alto Rio Paraná, PR, Brasil. Revista Brasileira de Botanica. Brazilian Journal of Botany, vol. 28, no. 4, pp. 821-834. http:// dx.doi.org/10.1590/S0100-84042005000400016.

FRANÇA, R.C.S., LOPES, M.R.M. and FERRAGUT, C., 2011. Structural and successional variability of periphytic algal community in an Amazonian lake during the dry and rainy season (Rio Branco, Acre). Acta Amazonica, vol. 41, no. 2, pp. 257-266. http://dx.doi.org/10.1590/S0044-59672011000200010.

GOLTERMAN, H.L., CLYMO, R.S. and OHMSTAD, M.A.M., 1978. Methods for physical and chemical analysis of freshwaters. 2nd ed. Oxford: Blackwell Scientific Publications. 213 p.

HASLE, G.R. and FRYXELL, G.A., 1970. Diatoms: cleaning and mounting for light and electron microscopy. Transactions of the American Microscopical Society, vol. 89, no. 4, pp. 496-474. http://dx.doi.org/10.2307/3224555.

HEGEWALD, E. and SILVA, P.C., 1988. Annotated catalogue of scenedesmus and nomenclaturally related Genera, including original descriptions and figures. Stuttgart: J. Cramer. 587 p.

HUSTON, M., 1994. Biological diversity: the coexistence of species on changing Landscapes. Cambridge: Cambridge Univ. Press. $681 \mathrm{p}$.

KOMÁREK, J. and ANAGNOSTIDIS, K., 1989. Modern approach to the classification system of Cyanophytes 4 - Nostocales. Algological Studies/Archive fur Hydrobiologie, vol. 82, no. 56, pp. 247-345.

KÖPPEN, W., 1948. Climatologia: con un estudio de los climas de la tierra. Fondo de México: Cultura Econômica. 479 p.

LARNED, T., 2010. A prospectus for periphyton: recente and future ecological research. Journal of the North American Benthological Society, vol. 29, no. 1, pp. 182-206. http://dx.doi. org/10.1899/08-063.1.

LOBO, E. and LEIGHTON, G., 1986. Estruturas de las fitocenosis planctónicas de los sistemas de desembocaduras de rios y esteros de la zona central de Chile. Revista de Biologia Marina, vol. 22, no. 1, pp. 143-170.

LOBO, E., 2013. O perifíton como indicador de qualidade de água. In A. SCHWARZBOLD, A.L. BURLIGA, and L.C. TORGAN, orgs. Ecologia do perifiton. São Carlos: RiMa. 413 p.

LOBO, E.A., WETZEL, C.E., ECTOR, L., KATOH, K., LANZA, S.B. and MAYAMA, S., 2010. Response of epilithic diatom communities to environmental gradients in subtropical temperate Brazilian rivers. Limnetica, vol. 29, no. 2, pp. 323-340.

LUND, J.W.G., KIPLING, C. and LE-CREN, E.D., 1958. The inverted microscope method of estimating algal number and the statistical basis of estimating by counting. Hydrobiologia, vol. 11, no. 2, pp. 143-170. http://dx.doi.org/10.1007/BF00007865.
MACKERETH, F.J.H., HERON, J. and TALLING, J.F., 1978. Water analysis: some revised methods for limnologists. Far Sawrey, Ambleside: Freshwater Biological Association Scientific Publication. $120 \mathrm{p}$

MIRETZKY, P., MAIDANA, N.I. and CIRELI, A.F., 2002. Stability of diatom composition in a variable lake environment: Lake Chascomús, Argentina. Limnology, vol. 2, no. 3, pp. 77-85. http://dx.doi.org/10.1007/s102010200009.

MURAKAMI, E.A., BICUDO, D.C. and RODRIGUES, L., 2009. Periphytic algae of the Garças Lake, Upper Paraná River floodplain: comparing the years 1994 and 2004. Brazilian Journal of Biology $=$ Revista Brasileira de Biologia, vol. 69, no. 2, (suppl.), pp. 459-468. http://dx.doi.org/10.1590/S151969842009000300002 . PMid:19738955.

NOZAKI, K., DARIJAV, K., AKATSUKA, T., GOTO, N. and MITAMURA, O., 2003. Development of filamentous green algae in the benthic algal community in a littoral sand-beach zone of Lake Biwa. Limnology, vol. 4, no. 3, pp. 161-165. http://dx.doi. org/10.1007/s10201-003-0104-3.

PADISÁK, J., CROSSETTI, L.O. and NASELLI-FLORES, L., 2009. Use and misuse in the application of the phytoplankton functional classification: a critical review with updates. Hydrobiologia, vol. 621, no. 1, pp. 1-19. http://dx.doi.org/10.1007/s10750-008-9645-0.

PEDRO, F., MALTCHIK, L. and BIANCHINI JUNIOR, I., 2006. Hydrologic cycle and dynamics of aquatic macrophytes in two intermittent rivers of the semi-arid region of Brazil. Brazilian Journal of Biology $=$ Revista Brasileira de Biologia, vol. 66, no. 2b, pp. 575-585. http://dx.doi.org/10.1590/S151969842006000400002 . PMid:16906290.

PETERSON, C.G., 1996. Response of Benthic algal communities to natural physical disturbance. In: R.J. STEVENSON, M.L. BOTHWELL and R.L. LOWE, orgs. Algal ecology - freshwater benthic ecosystems. San Diego: Academic Press, pp. 375-403.

PRESCOTT, G.W., BICUDO, C E.M. and VINYARD, W.C., 1982. A synopsis of North American desmids. In: G.W. PRESCOTT, org. Desmidiales. Lincoln: University Nebraska Press. 698 p. Part II. Desmidiaceae: Placodermae. Section 3.

REYNOLDS, C.S., HUSZAR, V., KRUK, C., NASELLI-FLORES, L. and MELO, S., 2002. Towards a functional classification of the freshwater phytoplankton. Journal of Plankton Research, vol. 24, no. 5, pp. 417-428. http://dx.doi.org/10.1093/plankt/24.5.417.

RODRIGUES, L., FONSECA, I.A., LEANDRINI, J.A., FELISBERTO, S.A. and SILVA, E.L.V., 2005. Distribuição espacial da biomassa perifítica em reservatórios e relação com o tipo de substrato. In: L. RODRIGUES, S.M.T. THOMAZ, A.A. AGOSTINHO and L.C. GOMES, eds. Biocenoses em reservatórios: padrões espaciais e temporais. São Carlos: RIMA, pp. 87-96.

ROUND, F.E., CRAWFORD, R.M. and MANN, D.G., 1990. The diatoms: biology and morphology of the Genera. Cambridge: University Press. 747 p.

SANT'ANNA, C.L., 1984. Chlorococcales (Chlorophyceae) do estado de São Paulo, Brasil. Cramer, Vaduz: Biblioteca Phycologica. no. 67

STATSOFT, 2011. STATISTICA (data analysis software system). Version 10. Tulsa: StatSoft Inc.

STEVENSON, R.J., 1996. An introduction to algal ecology in freshwater benthic habitats. In: R.J. STEVENSON, M.L. BOTHWELL and R.L. LOWE eds. Algal ecology freshwater benthic ecosystems. New York: Academic Press, pp. 3-30. 
TANIGUCHI, G.M., BICUDO, D.C. and SENNA, P.A.C., 2005. Gradiente litorâneo limnético do fitoplâncton e ficoperifíton em uma lagoa da planície de inundação do Rio Mogi-Guaçu. Brazilian Journal of Botany, vol. 28, no. 1, pp. 137-147. http:// dx.doi.org/10.1590/S0100-84042005000100011.

TANIWAKI, R.H., BORGHI, T.C., MAGRIN, A.G.E., CALIJURI, M.C., BOTTINO, F. and MOSCHINI-CARLOS, V., 2013. Structure and dynamics of the community of periphytic algae in a subtropical reservoir (state of São Paulo, Brazil). Acta Botanica Brasílica, vol. 27, no. 3, pp. 551-559. http://dx.doi.org/10.1590/ S0102-33062013000300013.

TELL, G. and CONFORTI, V., 1986. Euglenophyta Pigmentadas de La Argentina. Stuttgart: J. Cramer. 301 p.

TOLEDO JUNIOR, J.A.P., 1990. Informe preliminar sobre os estudos para obtenção de um índice do estado trófico de reservatórios de regiões quentes tropicais. São Paulo: Companhia de Tecnologia de Saneamento Ambiental. Internal report.
UTERMÖHL, H., 1958. Zur vervollkommnung der quantitativen phytoplankton methodik. Mitteilungen Internationale Vereiningung fuer Theoretische und Angewandte Limnologie, vol. 9, pp. 1-38.

VADEBONCOEUR, Y. and STEINMAN, A.D., 2002. Periphyton function in lake ecosystems. The Scientific World Journal, vol. 2, pp. 1-20. http://dx.doi.org/10.1100/tsw.2002.294. PMid:12805932.

VAN-DEN-HOEK, C., MANN, D.G. and JANHS, H.J.A., 1995. An Introduction to phycology. Cambridge: University of Cambridge Press. 623 p.

VERCELLINO, I.S. and BICUDO, D.C., 2006. Sucessão da comunidade de algas perifíticas em reservatório oligotrófico tropical (São Paulo, Brasil): comparação entre período seco e chuvoso. Brazilian Journal of Botany, vol. 29, no. 3, pp. 363-377. http://dx.doi.org/10.1590/S0100-84042006000300004.

WETZEL, R.G., 2001. Limnology: Lake and river ecosystems. 3rd ed. Orlando: Elsevier Science, pp. 1006. 